\title{
Uptake and efflux of 3-O-methyl-D-glucose in rat parotid cells
}

\author{
CEDRIC JURYSTA, KARIM LOUCHAMI, WILLY J. MALAISSE and ABDULLAH SENER \\ Laboratory of Experimental Hormonology, Brussels Free University (ULB), B-1070 Brussels, Belgium
}

Received April 19, 2013; Accepted May 2, 2013

DOI: $10.3892 /$ br.2013.102

\begin{abstract}
In the framework of recent investigations on the regulation of $\mathrm{D}$-glucose production by salivary glands, the aim of the present study was to compare the uptake of $3-\mathrm{O}-\left[{ }^{14} \mathrm{C}\right]$ methyl-D-glucose by rat parotid cells over a 6-min incubation period at $37^{\circ} \mathrm{C}$ to its efflux from prelabelled parotid cells, also incubated for $6 \mathrm{~min}$ at $37^{\circ} \mathrm{C}$. It was first assessed that the intracellular ${ }^{3} \mathrm{HOH}$ water space, whether expressed in absolute terms or relative to the total ${ }^{3} \mathrm{HOH}$ distribution space, is not significantly different between parotid cells obtained from either control rats or streptozotocin-induced diabetic rats. In the control rats, the uptake of 3-O-[ $\left[{ }^{14} \mathrm{C}\right]$ methyl-D-glucose corresponded, following correction for extracellular contamination, to a mean distribution space of $0.44 \pm 0.05 \mathrm{nl} / 10^{3}$ cells, representing $29.8 \pm 3.4 \%$ of the intracellular water space. The efflux of 3-O- $\left[{ }^{14} \mathrm{C}\right]$ methyl-Dglucose from prelabelled parotid cells, expressed relative to their initial radioactive content, averaged $82.9 \pm 4.8$ and $84.1 \pm 2.5 \%$ in control and diabetic rats, respectively. These findings suggest that the increased production of salivary D-glucose in diabetic subjects may be attributable to hyperglycemia, rather than to any major perturbation of the intrinsic processes involved, at least in parotid cells, in hexose handling.
\end{abstract}

\section{Introduction}

As recently reviewed (1), the involvement of D-glucose in parotid cell energetics was previously investigated with emphasis on such variables as the overall energy status estimated by the uptake of Tc-MIBI (2), the uptake of the hexose by intact parotid cells (3), its phosphorylation in cell homogenates $(4,5)$, the utilization and oxidation of the sugar $(4,5)$, the eventual accumulation of glycogen in situations of sustained hyperglycemia (6) and the role of mitochondrial carbonic anhydrase in the conversion of $\mathrm{CO}_{2}$ generated by the catabolism of D-glucose to bicarbonate anions (7). In the framework of recent studies on the regulation of $\mathrm{D}$-glucose production by

Correspondence to: Dr Cedric Jurysta, Laboratory of Experimental Hormonology, Brussels Free University (ULB), 808 Route de Lennik, B-1070 Brussels, Belgium

E-mail: cejuryst@ulb.ac.be

Key words: rat parotid cells, 3-O-methyl-D-glucose uptake and efflux salivary glands and on the expression of several glucose transporters possibly involved in the latter process $(8,9)$, the aim of the present study was to compare the uptake of $3-\mathrm{O}-\left[{ }^{14} \mathrm{C}\right]$ methyl-D-glucose by parotid cells, isolated from either control or diabetic rats, over a 6-min incubation at $37^{\circ} \mathrm{C}$ to its outflow from parotid cells prelabelled with the radioactive D-glucose analog, also over a 6-min incubation period.

\section{Materials and methods}

Animals. Control female Wistar rats and streptozotocin-induced diabetic rats were allowed free access to food and water up to the time of euthanasia, exsanguination and decapitation (9). The diabetic rats were obtained as previously described (10). The present study was approved by the ethics committee of Brussels Free University (ULB), Brussels, Belgium.

Experimental procedure. Parotid cells were prepared as previously described (3). Unless otherwise mentioned, the cells were incubated for $6 \mathrm{~min}$ at $37^{\circ} \mathrm{C}$ in groups of $160-330 \times 10^{3}$ cells placed in $100 \mu 1$ of a salt-balanced HEPES- and bicarbonate-buffered medium (3) supplemented with $1.0 \mathrm{mg} / \mathrm{ml}$ bovine serum albumin. To measure the distribution space of ${ }^{3} \mathrm{HOH}$ and $\mathrm{L}-\left[1-{ }^{14} \mathrm{C}\right]$ glucose, the incubation medium contained two radioactive tracers, unlabelled L-glucose $(0.4 \mathrm{mM})$ and 3-O-methylD-glucose $(8.3 \mathrm{mM})$. To measure the uptake of $3-\mathrm{O}-\left[{ }^{14} \mathrm{C}\right]$ methyl-D-glucose, the incubation medium contained a tracer amount of the ${ }^{14} \mathrm{C}$-labelled glucose analog and unlabelled 3-O-methyl-D-glucose $(8.3 \mathrm{mM})$. To measure the efflux of $3-\mathrm{O}-\left[{ }^{14} \mathrm{C}\right]$ methyl-D-glucose, groups of $4-5 \times 10^{6}$ cells were preincubated for $30 \mathrm{~min}$ at $37^{\circ} \mathrm{C}$ in $1,250 \mu \mathrm{l}$ of medium containing a tracer amount of $3-\mathrm{O}-\left[{ }^{14} \mathrm{C}\right]$ methyl-D-glucose and $8.3 \mathrm{mM}$ unlabelled 3-O-methyl-D-glucose. The cells were then submitted to three successive washes with $1.0 \mathrm{ml}$ of iced medium containing cytochalasin $\mathrm{B}(20 \mu \mathrm{M})$ and eventually incubated for $6 \mathrm{~min}$ at $37^{\circ} \mathrm{C}$ in the presence of 8.3 $\mathrm{mM}$ unlabelled 3-O-methyl-D-glucose. In all the cases, the cells were eventually separated from the incubation medium by centrifugation through an oil layer (3).

Statistical analysis. Results were presented as means \pm SEM together with the number of separate observations (n). The statistical significance of the differences between mean values was assessed using the Student's t-test. $\mathrm{P}<0.05$ was considered to indicate a statistically significant difference. 


\section{Results}

Intracellular water space assessment. The first objective of the present investigation was to assess the intracellular water space of isolated parotid cells, as estimated from the difference between the apparent distribution space of ${ }^{3} \mathrm{HOH}$ and $\mathrm{L}-\left[1-{ }^{14} \mathrm{C}\right]$ glucose (used as an extracellular marker). The results of the two experiments are provided in Table I. The mean values for the four variables listed in Table I, as measured in parotid cells prepared from normal rats, did not differ significantly between the first and second experiment $(P \geq 0.33)$. In the second experiment, the results recorded in normal rats did not differ significantly from those recorded in diabetic animals $(\mathrm{P} \geq 0.44)$. The overall mean values averaged $2.88 \pm 0.17 \mathrm{nl} / 10^{3}$ cells for the total ${ }^{3} \mathrm{HOH}$ space, $1.50 \pm 0.18 \mathrm{nl} / 10^{3}$ cells for the $\mathrm{L}-\left[1-{ }^{14} \mathrm{C}\right]$ glucose distribution space, $1.37 \pm 0.18 \mathrm{nl} / 10^{3}$ cells for the intracellular ${ }^{3} \mathrm{HOH}$ space and $49.3 \pm 5.7 \%$ for the ratio between the intracellular and total ${ }^{3} \mathrm{HOH}$ space ( $\mathrm{n}=5$ per group).

3-O-[ $\left.{ }^{14} C\right]$ methyl-D-glucose uptake. The second series of experiments was performed to measure the net uptake of $3-\mathrm{O}-\left[{ }^{14} \mathrm{C}\right]$ methyl-D-glucose by parotid cells from normal rats incubated for $6 \mathrm{~min}$ at $37^{\circ} \mathrm{C}$. Considering the radioactivity of the incubation medium, such a net uptake corresponded, following correction for extracellular contamination, to a mean intracellular distribution space of $0.44 \pm 0.05 \mathrm{nl} / 10^{3}$ cells $(n=10)$, representing $29.8 \pm 3.4 \%$ of the intracellular water space measured within the same experiment (experiment 1, Table I). The latter value was not significantly different $(\mathrm{P}>0.33)$ from that recorded in a previous study (3) following a 10-min incubation at $37^{\circ} \mathrm{C}$, i.e., $26.8 \pm 1.4 \%(\mathrm{n}=46)$.

3-O- $\left[{ }^{14} \mathrm{C}\right]$ methyl-D-glucose outflow. The third series of experiments was conducted to measure the outflow of radioactivity from parotid cells prelabelled with $3-\mathrm{O}-\left[{ }^{14} \mathrm{C}\right]$ methyl-D-glucose. Following a $30-\mathrm{min}$ preincubation at $37^{\circ} \mathrm{C}$ in the presence of 3-O- $\left[{ }^{14} \mathrm{C}\right]$ methyl-D-glucose, the cells underwent three washes. As shown in Fig. 1, the radioactive content of the washing medium decreased in an exponential manner. The coefficient of correlation between the logarithmic values for the radioactive content of the washing media and the number of washes amounted to $-0.9901(n=10 ; P<0.001)$. After the washes, the radioactive content of the parotid cells averaged $0.47 \pm 0.05$ and $0.45 \pm 0.01 \mathrm{dpm} / 10^{3}$ cells in the control and diabetic rats, respectively ( $\mathrm{n}=4$ in both cases). The latter two values were in agreement with the total radioactive content of the incubation medium and the parotid cells, as measured following incubation of the washed cells for $6 \mathrm{~min}$ at $37^{\circ} \mathrm{C}$. Thus, such a total radioactive content averaged $0.54 \pm 0.03(\mathrm{n}=16)$ and $0.54 \pm 0.02(\mathrm{n}=18) \mathrm{dpm} / 10^{3}$ cells in the control and diabetic rats, respectively. At the end of the 6-min incubation, the radioactive content of the incubation medium, expressed relative to the paired value for total radioactivity (incubation medium plus cells), averaged $82.9 \pm 4.8 \%(n=18)$ in the control rats and $84.1 \pm 2.5 \%(n=18)$ in the diabetic animals. The radioactive content of the cells after three washes corresponded to an apparent distribution space of $0.38 \pm 0.04 \mathrm{nl} / 10^{3}$ cells $(n=4)$, which was in agreement with the value recorded in the second series of experiments after only the 6-min incubation, where
Table I. Apparent distribution spaces in parotid cells following a 6-min incubation at $37^{\circ} \mathrm{C}$.

\begin{tabular}{|c|c|c|c|}
\hline \multirow[b]{2}{*}{ Spaces } & \multirow{2}{*}{ 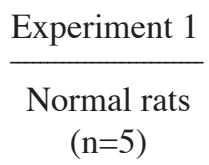 } & \multicolumn{2}{|c|}{ Experiment 2} \\
\hline & & $\begin{array}{l}\text { Normal rats } \\
\qquad(n=5)\end{array}$ & $\begin{array}{l}\text { Diabetic rats } \\
\qquad(\mathrm{n}=5)\end{array}$ \\
\hline $\begin{array}{l}\text { Total }{ }^{3} \mathrm{HOH} \\
\left(\mathrm{nl} / 10^{3} \text { cells }\right)\end{array}$ & $2.63 \pm 0.39$ & $3.15 \pm 0.32$ & $2.86 \pm 0.16$ \\
\hline $\begin{array}{l}\text { L- }[1-14 C] \text { glucose } \\
\left.\text { (nl/10 } 10^{3} \text { cells }\right)\end{array}$ & $1.16 \pm 0.29$ & $1.64 \pm 0.45$ & $1.71 \pm 0.13$ \\
\hline $\begin{array}{l}\text { Intracellular }{ }^{3} \mathrm{HOH} \\
\left(\mathrm{nl} / 10^{3} \text { cells }\right)\end{array}$ & $1.47 \pm 0.15$ & $1.51 \pm 0.55$ & $1.14 \pm 0.09$ \\
\hline $\begin{array}{l}\text { Intracellular/total } \\
{ }^{3} \mathrm{HOH}(\%)\end{array}$ & $58.5 \pm 6.0$ & $45.7 \pm 15.8$ & $43.7 \pm 4.4$ \\
\hline
\end{tabular}

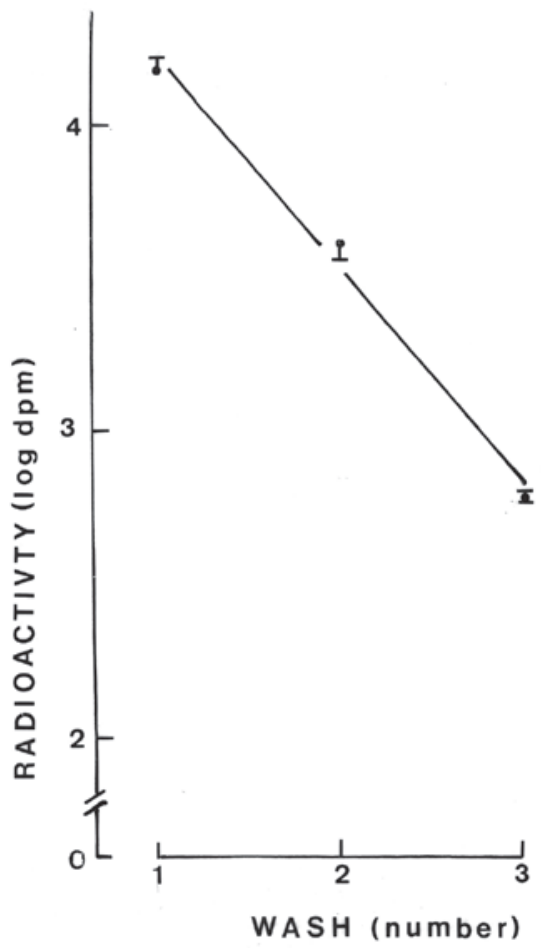

Figure 1. Logarithmic values for the radioactive content of a sample of washing media $(\mathrm{dpm} / 50 \mu \mathrm{l})$ over successive washes of parotid cells preincubated in the presence of 3-O-[ $\left.{ }^{14} \mathrm{C}\right]$ methyl-D-glucose. Mean values $( \pm \mathrm{SEM})$ refer to 2-4 individual measurements. The oblique line corresponds to the correlation line.

the apparent intracellular distribution space of $3-\mathrm{O}-\left[{ }^{14} \mathrm{C}\right]$ methyl-D-glucose averaged $0.44 \pm 0.05 \mathrm{nl} / 10^{3}$ cells. This finding demonstrates the adequacy of the washing procedure used in the third series of experiments.

Comparison of tracer uptake and outflow. As demonstrated by the apparent distribution space of 3-O-[ $\left.{ }^{14} \mathrm{C}\right]$ methyl-Dglucose in the parotid cells preincubated for $30 \mathrm{~min}$ at $37^{\circ} \mathrm{C}$ and then submitted to three washes $\left(0.38 \pm .04 \mathrm{nl} / 10^{3}\right.$ cells $)$ and the fractional outflow of radioactivity over an ensuing 6 -min incubation period $(82.5 \pm 2.7 \%)$, the outflow of the tracer 
corresponded to a volume of $\sim 0.32 \pm 0.03 \mathrm{nl} / 10^{3}$ cells, a value somewhat lower compared to the net uptake of the D-glucose analog, as measured also over the 6-min incubation period and corresponding to an apparent intracellular distribution space of $0.44 \pm 0.05 \mathrm{nl} / 10^{3}$ cells.

\section{Discussion}

The present study offers several new pieces of information. First, it documented that, expressed in either absolute terms or relative to the total water space, the intracellular water space of parotid cells does not differ significantly between normal and diabetic rats. Second, it extended a prior observation indicating that the apparent intracellular distribution space of 3-O-[ $\left.{ }^{14} \mathrm{C}\right]$ methyl-D-glucose at close-to-equilibrium values does not exceed $\sim 30 \%$ of the intracellular water space. Third, it revealed that the uptake of 3-O-[ $\left[{ }^{14} \mathrm{C}\right]$ methyl-Dglucose and its outflow from prelabelled parotid cells do not differ significantly between control animals and diabetic rats. Additionally, it documented that, within a 6-min incubation period at $37^{\circ} \mathrm{C}$, the majority of $3-\mathrm{O}-\left[{ }^{14} \mathrm{C}\right]$ methyl-D-glucose taken up during preincubation of parotid cells, is released from those cells over an ensuing incubation of $6 \mathrm{~min}$, with no significant difference observed between normal and diabetic rats.

Taken together, these findings suggest that the increased production of salivary D-glucose prevailing in diabetic subjects (8) is primarily attributable to the increased glycemia rather than to any significant perturbation in the intrinsic processes involved, at least in parotid cells, in hexose handling.

\section{Acknowledgements}

This study was supported by grant 3.4520 .07 (to A.S.) from the Belgian Foundation for Scientific Medical Research.

\section{References}

1. Jurysta C, Sener A and Malaisse WJ: Physiopathology of parotid cell energetics. Adv Biol Chem: doi: 10.4236/abc.2013.32020.

2. Blocklet D, Jijakli H, Sener A, Schoutens A and Malaisse WJ: ${ }^{99 m}$ Tc-sesta-(2-methoxy-isobutyl-isonitrile) uptake by pancreatic islets, parotid cells, and mammary carcinoma cells. Endocrine 9: 113-117, 1998.

3. Ramirez R, Courtois P, Ladrière L, Kadiata MM, Sener A and Malaisse WJ: Uptake of D-mannoheptulose by rat erythrocytes, hepatocytes and parotid cells. Int J Mol Med 8: 37-42, 2001.

4. Scruel O, Vanhoutte C, Sener A and Malaisse WJ: Interference of D-mannoheptulose with D-glucose phosphorylation, metabolism and functional effects: comparison between liver, parotid cells and pancreatic islets. Mol Cell Biochem 187: 113-120, 1998.

5. Malaisse WJ, Kadiata MM, Scruel O and Sener A: Esterification of D-mannoheptulose confers to the heptose inhibitory action on D-glucose metabolism in parotid cells. Biochem Mol Biol Int 44: 625-633, 1998.

6. Ladrière L, Louchami K, Laghmich A, Malaisse-Lagae F and Malaisse WJ: Labeling of pancreatic glycogen by D-[U- $\left.{ }^{14} \mathrm{C}\right]$ glucose in hyperglycemic rats. Endocrine 14: 383-397, 2001.

7. Sener A, Jijakli H, Zahedi Asl S, Courtois P, Yates AP, Meuris S, Best LC and Malaisse WJ: Possible role of carbonic anhydrase in pancreatic islets: enzymatic, secretory, metabolic, ionic, and electrical aspects. Am J Physiol Endocrinol Metab 292: E1624-E1630, 2007.

8. Jurysta C, Bulur N, Oguzhan B, Satman I, Yilmaz TM, Malaisse WJ and Sener A: Salivary glucose concentration and excretion in normal and diabetic subjects. J Biomed Biotechnol: May 26, 2009 (Epub ahead of print). doi: 10.1155/2009/430426.

9. Jurysta C, Nicaise C, Cetik S, Louchami K, Malaisse WJ and Sener A: Glucose transport by acinar cells in rat parotid glands. Cell Physiol Biochem 29: 325-330, 2012.

10. Belkacemi L, Selselet-Attou G, Hupkens E, Nguidjoe E, Louchami K, Sener A and Malaisse WJ: Intermittent fasting modulation of the diabetic syndrome in streptozotocin-injected rats. Int J Endocrinol: Jan 12, 2012 (Epub ahead of print). doi: $10.1155 / 2012 / 962012$. 